\title{
On the Linkage between the Extreme Drought and Pluvial Patterns in China and the Large-Scale Atmospheric Circulation
}

\author{
Zengxin Zhang, ${ }^{1,2}$ Qiu Jin, ${ }^{1}$ Xi Chen, ${ }^{3}$ Chong-Yu Xu, ${ }^{4,5}$ and Shanshan Jiang ${ }^{1}$ \\ ${ }^{1}$ Joint Innovation Center for Modern Forestry Studies, College of Biology and the Environment, Nanjing Forestry University, \\ Nanjing 210037, China \\ ${ }^{2}$ State Key Laboratory of Satellite Ocean Environment Dynamics, Second Institute of State Oceanic Administration, \\ Hangzhou 310012, China \\ ${ }^{3}$ State Key Laboratory of Hydrology-Water Resources and Hydraulic Engineering, Hohai University, Nanjing 210098, China \\ ${ }^{4}$ State Key Laboratory of Water Resources and Hydropower Engineering Science, Wuhan University, Wuhan 430072, China \\ ${ }^{5}$ Department of Geosciences, University of Oslo, 0316 Oslo, Norway
}

Correspondence should be addressed to Zengxin Zhang; nfuzhang@163.com

Received 15 March 2016; Revised 24 May 2016; Accepted 14 June 2016

Academic Editor: Hyunhan Kwon

Copyright (c) 2016 Zengxin Zhang et al. This is an open access article distributed under the Creative Commons Attribution License, which permits unrestricted use, distribution, and reproduction in any medium, provided the original work is properly cited.

\begin{abstract}
China is a nation that is affected by a multitude of natural disasters, including droughts and floods. In this paper, the variations of extreme drought and pluvial patterns and their relations to the large-scale atmospheric circulation have been analyzed based on monthly precipitation data from 483 stations during the period 1958-2010 in China. The results show the following: (1) the extreme drought and pluvial events in China increase significantly during that period. During 1959-1966 timeframe, more droughts occur in South China and more pluvial events are found in North China (DSC-PNC pattern); as for the period 1997-2003 (PSC-DNC pattern), the situation is the opposite. (2) There are good relationships among the extreme drought and pluvial events and the Western Pacific Subtropical High, meridional atmospheric moisture flux, atmospheric moisture content, and summer precipitation. (3) A cyclone atmospheric circulation anomaly occurs in North China, followed by an obvious negative height anomaly and a southern wind anomaly at $850 \mathrm{hPa}$ and $500 \mathrm{hPa}$ for the DSC-PNC pattern during the summer, and a massive ascending airflow from South China extends to North China at $\sim 50^{\circ} \mathrm{N}$. As for the PSC-DNC pattern, the situation contrasts sharply with the DSCPNC pattern.
\end{abstract}

\section{Introduction}

Droughts and floods are among the world's costliest natural disasters. In recent years, the increase of the frequency and intensity of floods and droughts has initiated wide concern [1-6]. China is facing an increase of extreme climatological events, such as droughts and floods [7]. Some investigators have studied the decadal and interdecadal variability of precipitation in China for the past 50 years and found that the prolonged droughts in North China coincide with the flooding conditions in the Yangtze River basin and South China in the period from the end of the 1970s to the beginning of the 21st century [8-10].

Over the past decade, various indices have been proposed to detect and monitor drought and pluvial events; however, the precise quantification of droughts and pluvial spells is difficult $[4-6,11]$. The SPI was first presented by Mckee et al. [12] based on the long-term precipitation record for a given period. This long-term record is fitted to a probability distribution, which is then transformed into a normal distribution so that the mean SPI for the location and desired period is zero [13]. The SPI has been used in many studies and it has proved to be a useful tool in the estimation of the intensity and duration of drought events $[5,12,14-16]$. The SPI is a multiscale index that allows the objective comparison of dry/wet conditions of regions with different hydrological regimes. Typical time scales used are 1, 3, 6, 12, and 24 months (SPI-1, SPI-3, SPI6 , SPI-12, and SPI-24, resp.) and SPI-24 is usually regarded as hydrological drought [17]. SPI-24 also can be used to monitor surface water resources, for example, river flows [18]. 
Many studies are aiming to increase the understanding of the drought and flood properties and underlying causes; however, the causes of droughts and floods are complex [19-21]. For example, Dai et al. [6] found that the globally very dry areas have more than doubled since the 1970s, with a large jump in the early 1980s due to an ENSO-induced precipitation decrease. Barlow et al. [22] found that the cold phase ENSO event and unusually warm ocean water in the Western Pacific contributed to the severe drought of 19982001 in central and southwest Asia. On the other hand, Ding et al. [23] pointed out that the influence of SSTs and ENSO events on the summer precipitation in China cannot be used to explain the variance of precipitation. This implies that other external forcing factors can also exert an important effect on the interdecadal variability of the summer precipitation in China. $\mathrm{Ma}$ and $\mathrm{Fu}$ [24] found that the decreasing precipitation in recent years in North China could be one of the key factors causing intensifying and increasing drought events. Ding et al. [19] inferred that the rainfall variations in Northern China were related to the weakening of the East Asian summer monsoon since the late 1970s. Zhu et al. [21] found that the atmospheric heating over South China might be the main force to drive the southwesterly winds and updrafts and strengthen the summer precipitation in South China. Wu [25] also reported that the Indian summer monsoon circulation underwent two weakening processes in the last 50 years, with the first one occurring in the mid-1960s and the second one in the late 1970s.

Still, it is not yet clear how the weakening of the Asian (especially the East Asian) summer monsoon affects the significant southward shift of precipitation patterns in East China. Furthermore, the reason why the interdecadal weakening of the Asian summer monsoon occurred remains an open question [19]. Ding et al. [23] thought that the change in snow cover in the preceding winter and spring over the Tibetan Plateau (TP) might be related to the Asian summer monsoon and summer precipitation variability of China. Jiang et al. [26] pointed out that precipitation decreases in Northeastern Asia and increases over China when the Western Pacific Subtropical High (WPSH) strengthens and monsoon flow becomes weaker over Eastern Asia. Chou et al. [27] analyzed the relationship between summer rainfall in Taiwan and the large-scale atmospheric circulation and found that the summer rainfall of Taiwan is highly sensitive to the North Pacific high pressure. Huang et al. [3] determined that the East Asian monsoon (EAM) system is closely related to the teleconnection pattern of the meridional uppertropospheric wind anomalies along the westerly jet over East Asia.

Although many researchers have addressed the changing properties of summer precipitation and possible underlying causes in some regions of China $[3,19,23,28]$, the extreme drought and pluvial changes and their relationship with the large-scale atmospheric circulation over China have not been analyzed thoroughly so far. Our previous studies have clarified a drying tendency in North China, and the abrupt decrease of moisture flux in North China is the major reason why the frequency of drought in North China is becoming higher. The weakening Asian summer monsoon caused the decreasing northward propagation of moisture flux in East Asia $[16,29]$. Based on our previous studies and the research of others, we assume that the variations of the WPSH might make a great impact on the pattern of extreme drought and pluvial events in China.

The objectives of this study are (1) to explore the longterm changing properties of extreme drought and pluvial events in China; (2) to examine the relationship between the WPSH and the extreme drought and pluvial events in China; and (3) to investigate the influences of large-scale atmospheric circulation on the occurrence of drought and pluvial events in China with the aim of understanding the possible causes behind drought and pluvial episodes across China. This paper has the potential to help improve our understanding of the changes of extreme drought and pluvial events in China and thus to enhance human mitigation to drought and flood hazards under the changing climate.

\section{Study Region and Data}

The study covers the whole China region. Due to its special geographic climate conditions, China is vulnerable to severe floods and droughts. Almost two-thirds of land area in China is prone to flood disasters of all types and severities, and most of the places suffer from drought disasters of varied degrees. Since 1990, the average loss resulting from floods has amounted to about $1.5 \%$ of GDP over the same period, and the average economic loss resulting from droughts has been over 1\% of GDP (http://www.mwr.gov.cn/english/fcdrc.html).

In this paper, monthly precipitation data from 483 National Meteorological Observatory (NMO) stations are used. These stations were chosen because of their good quality and continuous data records for the period 19582010. The data are provided by the National Climatic Centre (NCC) of the China Meteorological Administration (CMA). The topographic map of China and the gauging stations can be referred to in Figure 1.

The whole layer of moisture content and moisture flux is analyzed based on the NCAR/NCEP reanalysis dataset covering from 1958 to 2010. In the actual atmosphere, the moisture is very low over $300 \mathrm{hPa}$, so $p=300 \mathrm{hPa}$ will be used in the calculation. The moisture content $(Q)$ and meridional moisture transport flux $\left(Q_{v}\right)$ were calculated based on the following equations [30]:

$$
\begin{gathered}
Q=-\frac{1}{g} \int_{p_{s}}^{p} q(P) d P \\
Q_{v}(x, y, t)=\frac{1}{g} \int_{p_{s}}^{p} q(x, y, p, t) v(x, y, p, t) d p
\end{gathered}
$$

where $q$ is the specific humidity, $p_{s}$ is surface pressure, $p$ is atmospheric top pressure, $g$ is acceleration of the gravity, and $v$ is the meridional components of the wind field.

The atmospheric circulation analysis is mainly based on the $850 \mathrm{hPa}$ and $500 \mathrm{hPa}$ geopotential height and wind fields from the National Centers for Environmental Prediction (NCEP) reanalysis, which has a spatial resolution of $2.5^{\circ}$ latitude-longitude. 


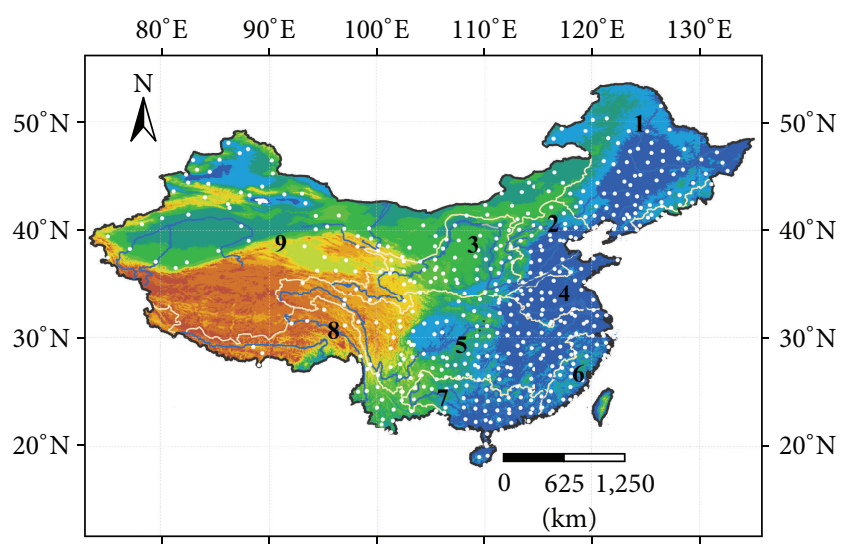

$80^{\circ} \mathrm{E} \quad 90^{\circ} \mathrm{E} \quad 100^{\circ} \mathrm{E} \quad 110^{\circ} \mathrm{E} \quad 120^{\circ} \mathrm{E} \quad 130^{\circ} \mathrm{E}$

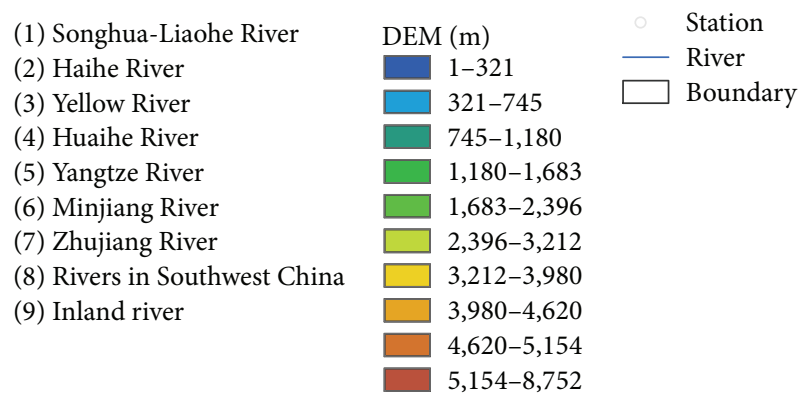

Figure 1: Locations of 483 rain gauge stations of China.

The China Meteorological Administration (CMA) has defined a series of indices to quantify and monitor the activity of WPSH, including the area index, the intensity index, the position of ridges, the west boundary, and the north boundary. In this paper, the area index and the intensity index were chosen to measure the WPSH. The intensity index of WPSH is defined as the average $H$ value for all of the grid points where $H>5860 \mathrm{gpm}$ by using the $500 \mathrm{hPa}$ height. The total number of the grid points with $H>5860 \mathrm{gpm}$ in the domain is referred to as the area index of WPSH. For the WPSH over the Western Pacific, the domain is $10 \sim 40^{\circ} \mathrm{N}$, $110 \sim 180^{\circ} \mathrm{E}$ [31]. The flood and drought disaster areas come from national records by the Ministry of Water Resources of the People's Republic of China (MWR) (http://www.mwr.gov $. \mathrm{cn} /)$.

\section{Methods}

The SPI calculation for any location is based on the long-term precipitation record for a desired period [12]. The drought is classified into four categories: mild, moderate, severe, and extreme drought. A clear and detailed description of the steps required to calculate the SPI is provided by Lloyd-Hughes and Saunders [32]. The SPI at a 24-month time scale is used to define the hydrological drought in this work and the gamma distribution is used to approximate the observed probability distribution function of the precipitation amount.

To compare the drought intensity in China, the drought intensity $\left(D_{i}\right)$ is adopted in this study. The drought intensity can be defined as

$$
D_{i}=\frac{\sum_{i=1}^{n} \operatorname{SPI}(i)}{n},
$$

where $\operatorname{SPI}(i)$ is the SPI value, $i$ is the sequential month of a time series of a drought, and $n$ is the months.

The Empirical Orthogonal Function (EOF) is a popular tool in various scientific areas such as meteorology, geology, and geography [33]. The EOF method is used to analyze the main drought features of spatial and temporal variability. The EOF analysis is a statistical technique that linearly transforms an original set of variables into a substantially small set of uncorrelated variables representing most of the information of the original set of variables [34]. Basically, the goal of EOF analysis is to reduce the dimensionality of the original dataset. A small set of uncorrelated variables is much easier to understand and handle for further analyses than a larger set [35].

\section{Results and Discussions}

4.1. The Extreme Drought and Pluvial Patterns in China. The aspects of extreme dryness and wetness in China during the past 50 years have been evaluated by SPI-24 using the observed precipitation datasets. Figure 2 shows the spatial and temporal distributions of the dryness and wetness of SPI in China by using the method of EOF. It is noted that the first three principal components explain $11.2 \%, 8.6 \%$, and $7.7 \%$ of the total variation of SPI-24, respectively.

From Figure 2, we can find that there are three main patterns of extreme droughts and pluvials in China during the period 1958-2010. The three main patterns are "+-" pattern, "- + -" pattern, and “+ - + " pattern in East China, respectively ("+" means extreme droughts and "" indicates extreme pluvials). From the first mode of EOF (EOF1, Figure 2(a)), higher positive values occur in South China and Northwest China, while negative values are found in North China. The drought and pluvial pattern in North China is negatively related to the change in South China and Northwest China, which indicates that the drought and pluvial pattern in East China has an obvious south-north antisymmetric pattern as a whole.

The first principal component (PC1) presents the longterm trends of drought and pluvial events over the whole country during the period 1958-2010 (Figure 2(d)). During the past 50 years, we can find that the pluvial events increase significantly in South China (e.g., Zhujiang River basin and Minjiang River basin) and Northwest China (e.g., Tarim River basin). However, drought events increase significantly in North China (e.g., Yellow River basin, Haihe River basin, and Liaohe River basin) at the same period. It is also noted that more extreme drought and pluvial events occur in China during the periods of 1959-1966 and 1997-2003, respectively. During the period of 1959-1966, more drought events appeared in South China and Northwest China, while more pluvial events occurred in North China. As for the period of 1997-2003, a contrary drought and pluvial pattern can be found with more droughts in North China and more pluvial events in South China and Northwest China. It should be noted that although the pluvial events increase in Northwest China, this region is located in an arid-semiarid area, so the increase in pluvial events across Northwest China is just a sign of the climate becoming wet, 

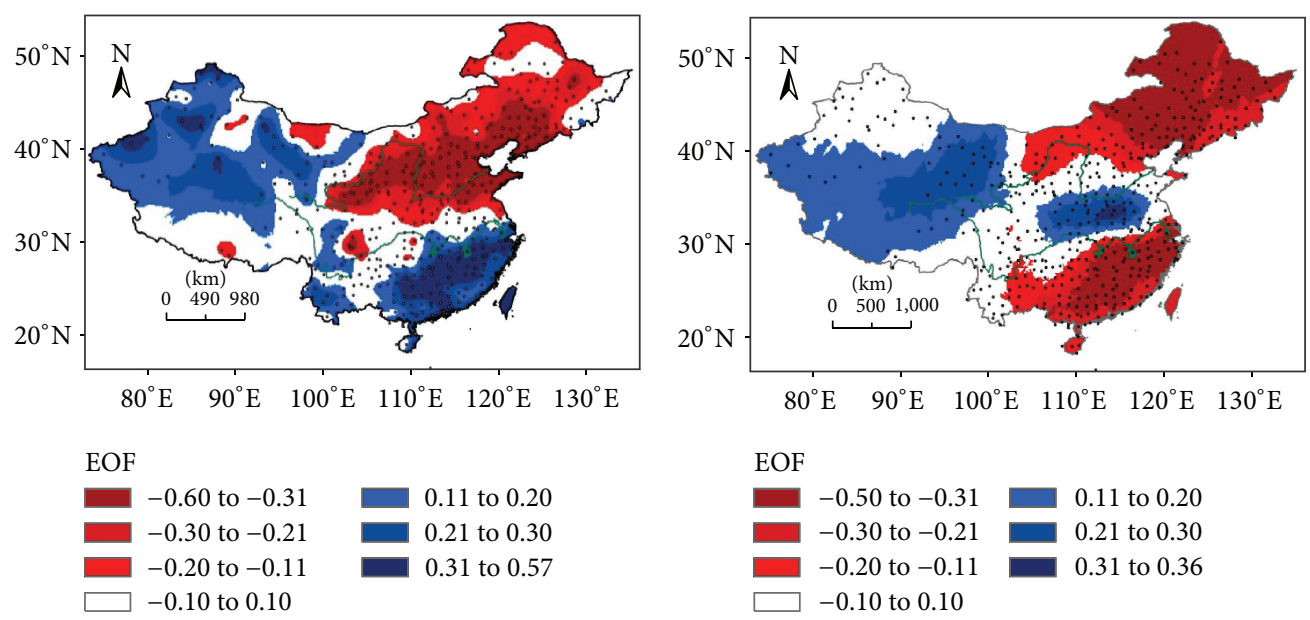

(a) EOF1

(b) EOF2
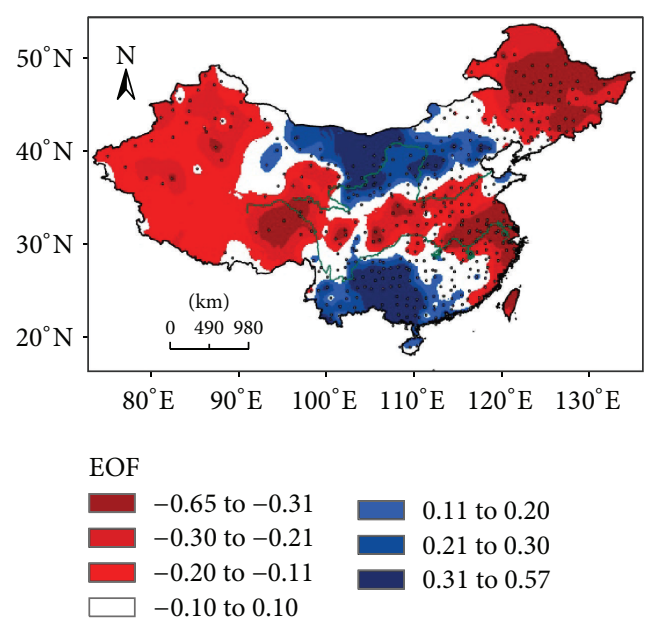

(c) EOF3

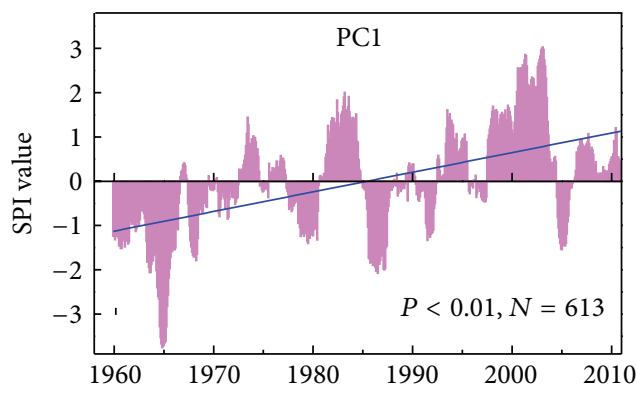

(d)

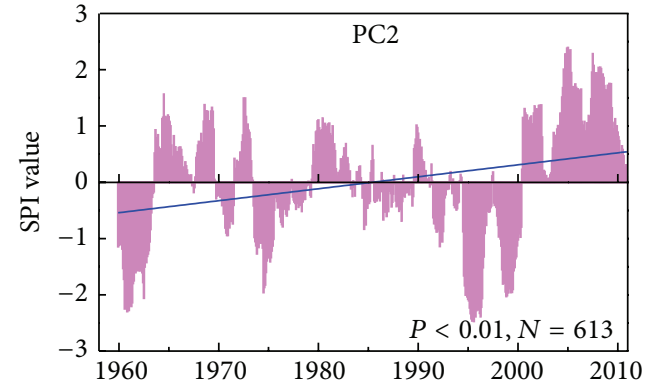

(e)

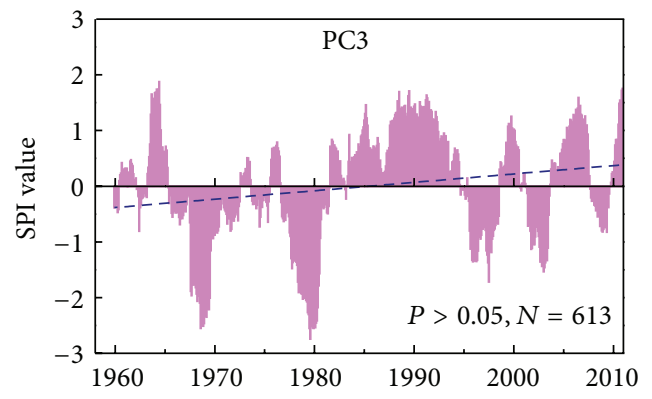

(f)

FIgURE 2: The first three EOF and PC of SPI-24 in China during the period of 1958-2010 (solid linear line in (d) and (e) means the significant linear trend at $>95 \%$ level and the dashed linear line in (f) means a nonsignificant linear trend). 


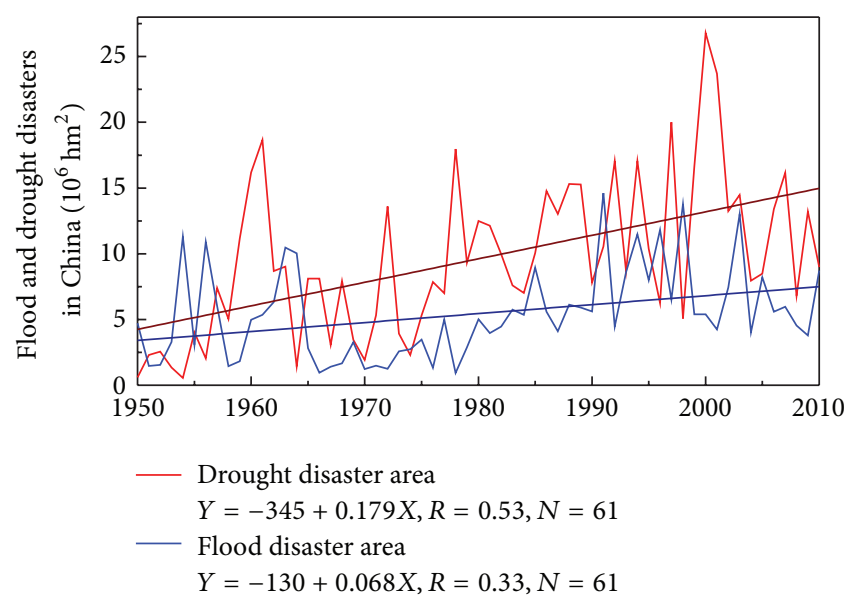

(a)

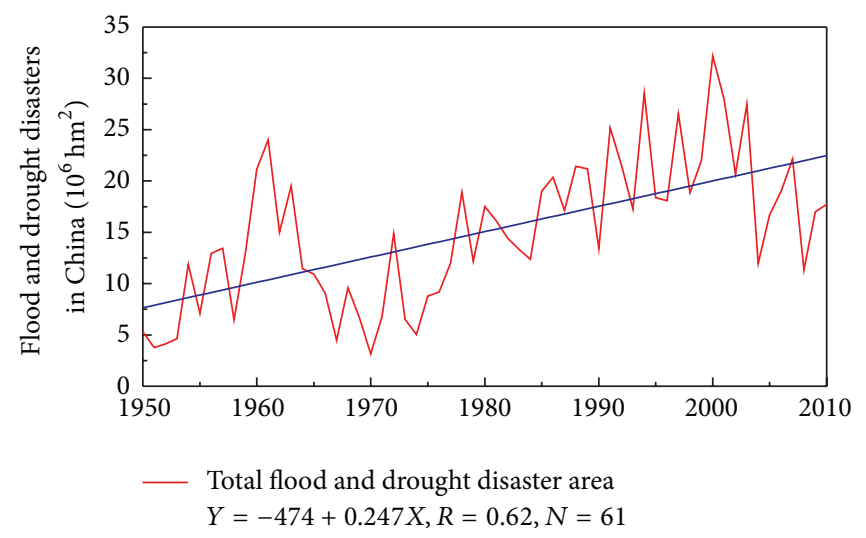

(b)

Figure 3: The flood and drought disaster area in China during the period 1950-2010 ((a) the drought and flood disaster area, resp.; (b) the total disaster area of drought and flood).

which is quite different to that of South China. The pluvial events increasing in South China might indicate more floods occurring in this period. In this paper, the periods of 19591966 represent the pattern of more droughts in South China and more pluvials in North China, while the periods of 1997-2003 indicate more droughts in North China and more pluvials in South China. The drought in South China and pluvial pattern in North China and the pluvial pattern in South China and drought in North China are abbreviated as DSC-PNC and PSC-DNC pattern, respectively. Figure 2(b) shows the second mode of EOF; we can find the extreme drought events increasing significantly in Northeast China (e.g., Songhua-Liaohe River basin) and Southeast China (e.g., Minjiang River basin and Zhujiang River basin) with more pluvial events increasing significantly in central China (Haihe River basin) and Northwest China (Tarim River basin). Combined with Figure 2(e), it can be inferred that more droughts occur in Southeast China and Northeast China in this period. The third mode of EOF shows that extreme droughts appear in Northeast China (e.g., Songhuajiang River basin), East China (e.g., the middle and lower Yangtze River basin), and Northwest China (e.g., the Tarim River basin) while pluvial events increase in Southwest China and North China (e.g., the upper and middle Yellow River and inland river basin). However, Figure 2(f) shows a nonsignificant linear trend. From the flood and drought disaster areas in China (Figure 3(a)), we can see that both the flood and drought disaster areas increased significantly during the past 60 years. The flood and drought disaster areas increase at an average annual rate of 68,000 and 179,000 hectares per year, respectively. Figure 3 (b) shows the long-term trends of the sum of flood and drought disaster areas. We can note that the drought and flood disaster areas in China increase significantly at the rate of about 247,000 hectares per year. These results are well matched with the SPI values of China. In this research, we mainly analyze the first mode of EOF and PC1 which can present the main features of the extreme droughts and pluvials in China during the past 50 years.
4.2. The Variation of the Western Pacific Subtropical High. Figure 4 shows the comparison between the annual and summer precipitation anomalies in China for the DSC-PNC and PSC-DNC patterns. We can see that the precipitation anomalies show south-north antisymmetric pattern during the period of 1958-2010 in East China which is well matched with the extreme drought and pluvial patterns. Moreover, we can find that the summer precipitation anomalies can represent the annual precipitation anomalies to a great extent; thus, the summer precipitation might make a great impact on the drought and flood in China. Huang et al. [3] also showed that the variability of the East Asian monsoon climate system might be linked with the occurrence of severe floods in the Yangtze and Huaihe River valleys and prolonged droughts in North China.

As a direct influencing factor to the Asian summer monsoon and precipitation, the WPSH is subject to sharp fluctuations in strength and location every year. Many researches reveal that the WPSH is closely related to the intensity of the East Asian summer monsoon and precipitation over East China. Namely, the strength and location of the WPSH could lead to the changes of the patterns of summer precipitation over East China [21, 26, 31, 36-38]. The WPSH might play an important role in the flood and drought pattern of China. Figure 5 shows the strength and location of the WPSH at $500 \mathrm{hPa}$ geopotential during the periods of 1959-1966 (DSCPNC pattern) and 1997-2003 (PSC-DNC pattern) in summer (JJA). The geopotential height at $500 \mathrm{hPa}$ for the Northern Hemisphere has a great change for the DSC-PNC and PSCDNC patterns. It can be noted that the strength of WPSH is very weak for the DSC-PNC pattern when more droughts occur in South China and more pluvial events appear in North China. However, as for the PSC-DNC pattern, the WPSH becomes much stronger, and the drought and pluvial pattern shows an opposite trend (Figure 2). It can be seen that negative geopotential high anomalies appear in China at $500 \mathrm{hPa}$ during the period from 1959 to 1966 (Figure 5(c)) while positive anomalies occur in China during the period from 1997 to 2003 (Figure 5(d)). For the DSC-PNC pattern, 

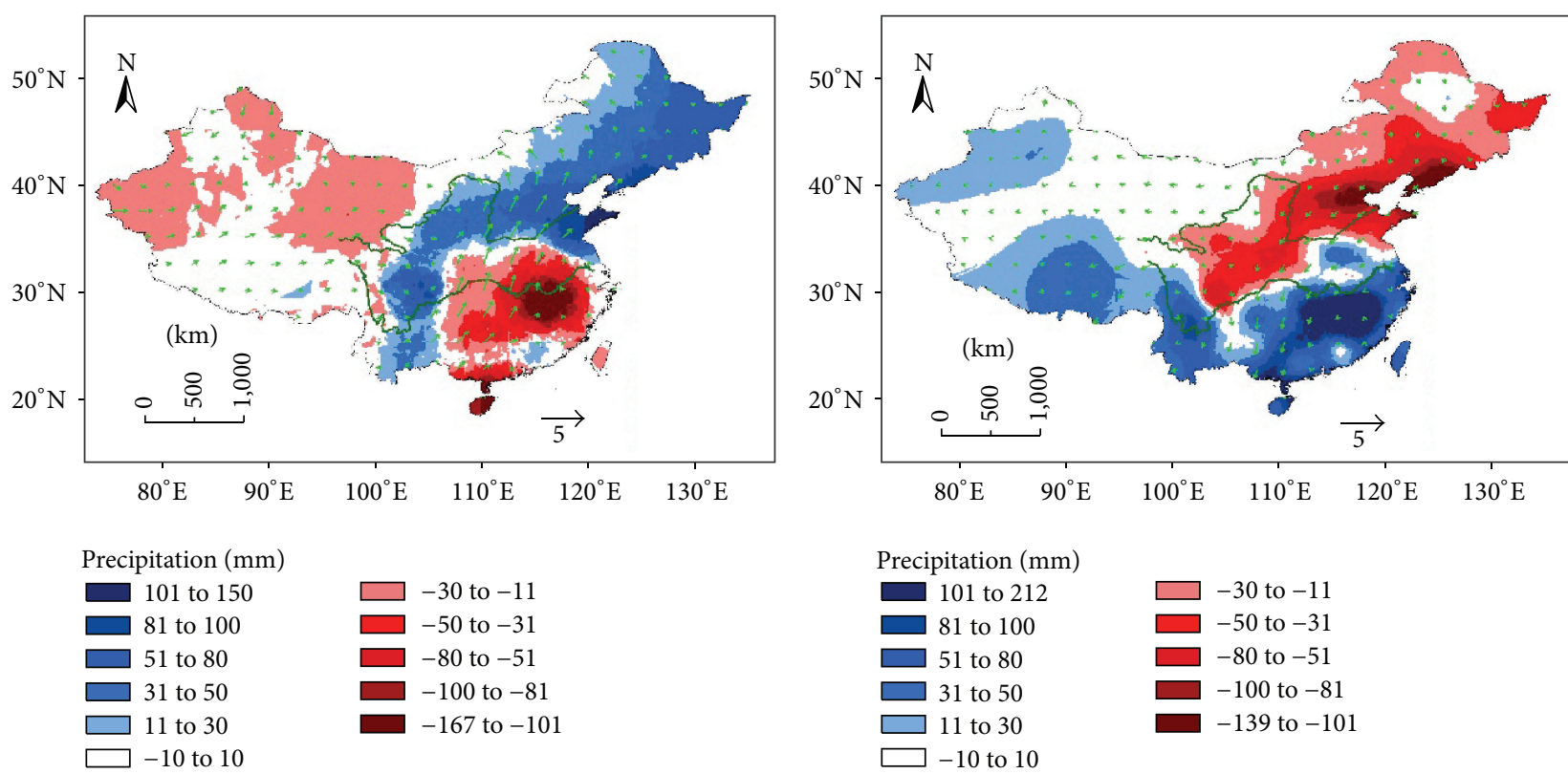

(a) Annual precipitation anomalies (1959-1966)

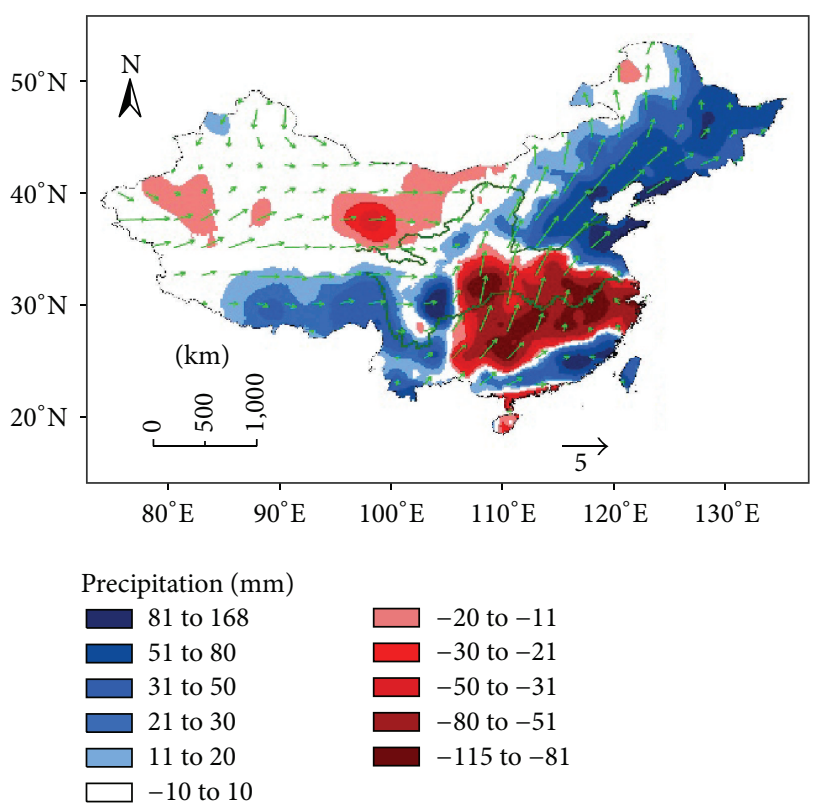

(c) Summer precipitation anomalies (1959-1966)

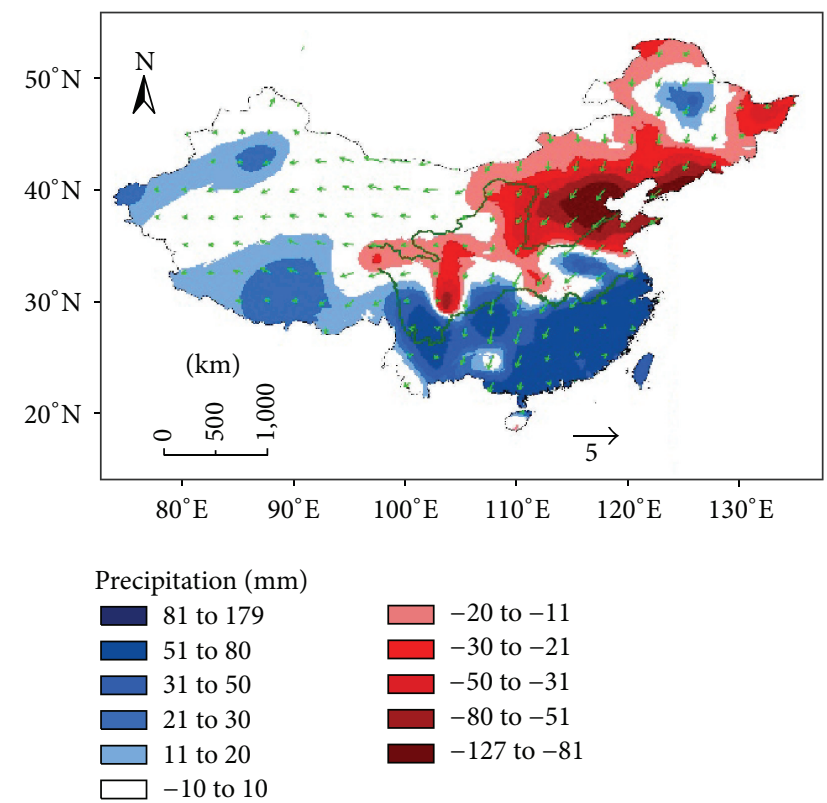

(d) Summer precipitation anomalies (1997-2003)

FIGURE 4: Comparison of the annual and summer mean precipitation anomalies in China during the periods of 1959-1966 and 1997-2003.

all of China is controlled by negative geopotential anomalies while positive geopotential anomalies appear for the PSCDNC pattern.

The comparison of the SPI value, drought and flood disaster areas, and the index of the Western Pacific Subtropical High can be found in Figure 6. In this figure, the SPI value is the annual mean SPI value based on the PC1; the drought and flood disaster areas are the sum of the drought and flood disaster areas. We can find that both the area and intensity index increase significantly during the period 1958-2010 and in most cases the area and intensity index of the WPSH agree well with the drought and flood disaster areas. In the 1960s and 1970s, the SPI value, the drought disaster area, the flood disaster area, and the sum of the drought and flood areas are fewer than usual, and the area and intensity index are also smaller than usual, while the situation is the opposite in the 1990s and 2000s.

To analyze the relationship between the WPSH and the extreme drought and pluvial in East China during the period 1958-2010, the time-latitude cross section averaged over $110-120^{\circ} \mathrm{E}$ of WPSH, meridional moisture flux, moisture content, and precipitation in summer are shown in Figure 7. 


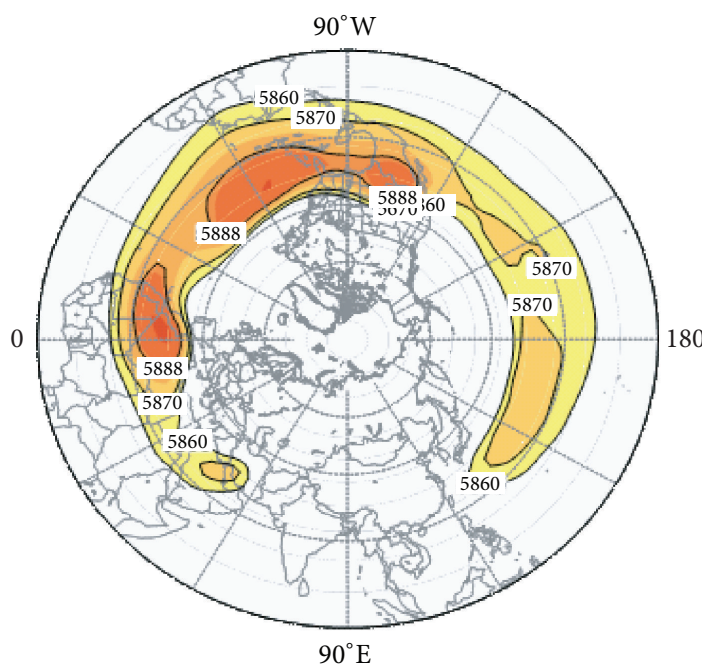

(a)

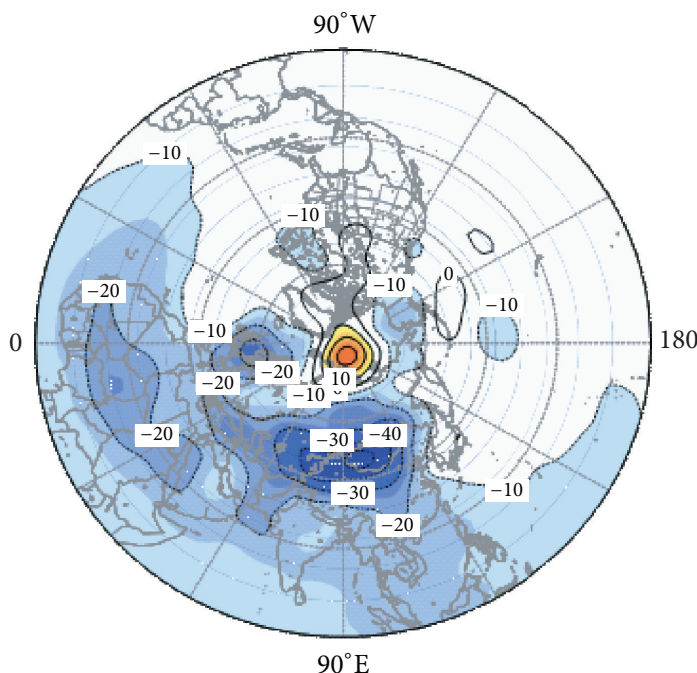

(c)

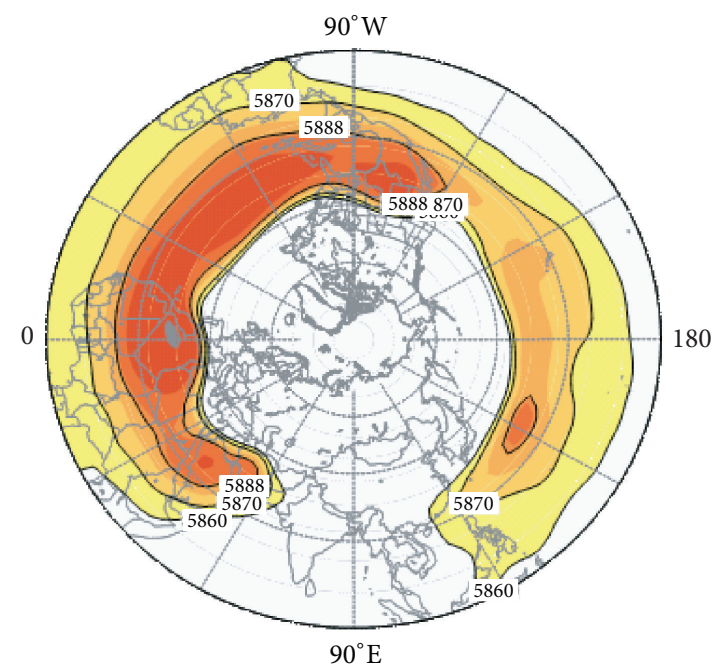

(b)

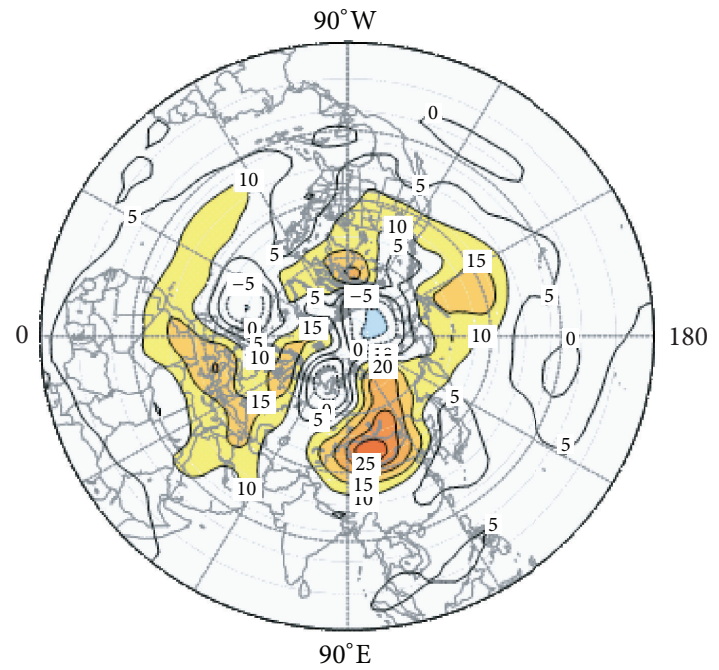

(d)

FIGURE 5: The mean and difference of geopotential height distribution at $500 \mathrm{hPa}$ during the summer (JJA). The mean for the periods of (a) 1959-1966 and (b) 1997-2003, (c) the difference between 1959-1966 and 1958-2010, and (d) the difference between 1997-2003 and 1958-2010. Unit: $\mathrm{m}$.

From this figure, obvious negative WPSH anomalies can be found before the mid-1970s, while positive anomalies occur during the mid-1970s. The anomaly distribution of the meridional moisture transport flux $\left(Q_{v}\right)$ is opposite to that of the WPSH. More moisture flux comes from south to north in the 1960s and the early and mid-1970s, and less moisture flux reaches North China during the same time period. The moisture content anomalies agree well with the meridional moisture flux distribution. During the period 1958-1975, more moisture content could be found in North China, while less moisture content appears in North China since the mid-1970s. More precipitation in North China and less precipitation in South China were found in the 1960 s and 1970s. Still, less precipitation in North China and more precipitation in South China appeared during the 1990s and 2010s. It can be concluded that the phase of WPSH is opposite to that of meridional moisture flux, moisture content, and precipitation. Ding et al. [19] also investigated the weakening of the East Asian summer monsoon, which caused the rainfall decrease in North China since the late 1970s. Chou et al. [27] also reported that there is a good relationship between summer rainfall in Taiwan and the North Pacific high pressure which agrees well with our results. Qian et al. [39] also found that there is a good relationship between summer precipitation and atmospheric circulation over China, and the East Asian monsoon became anomalously weak with successive increase in the area of WPSH.

4.3. The Extreme Drought and Pluvial and Large-Scale Atmospheric Circulation. To support the arguments stated above, we show in Figure 8 the summer mean and difference of meridional circulation cells over $105-120^{\circ} \mathrm{E}$. The upper panel 

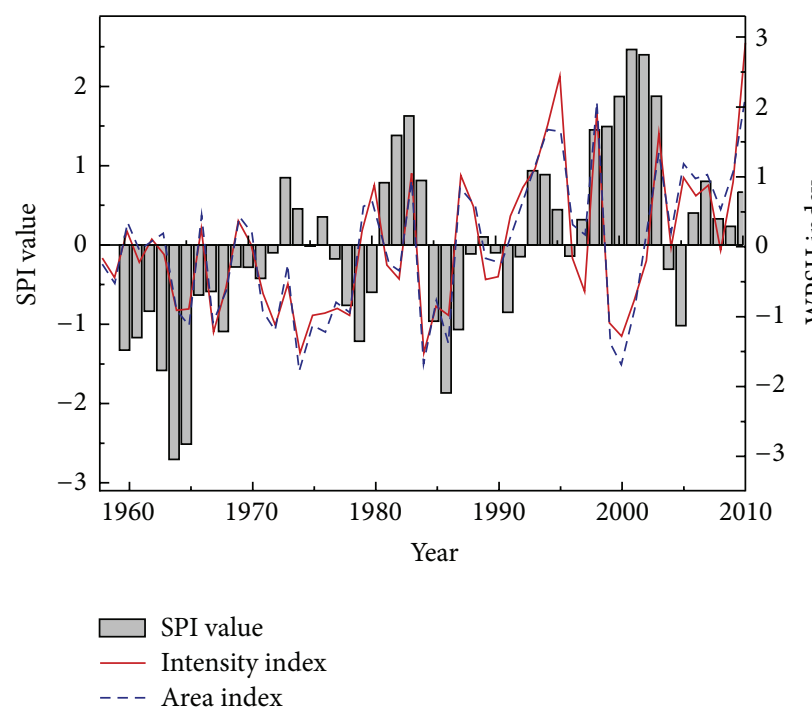

(a)

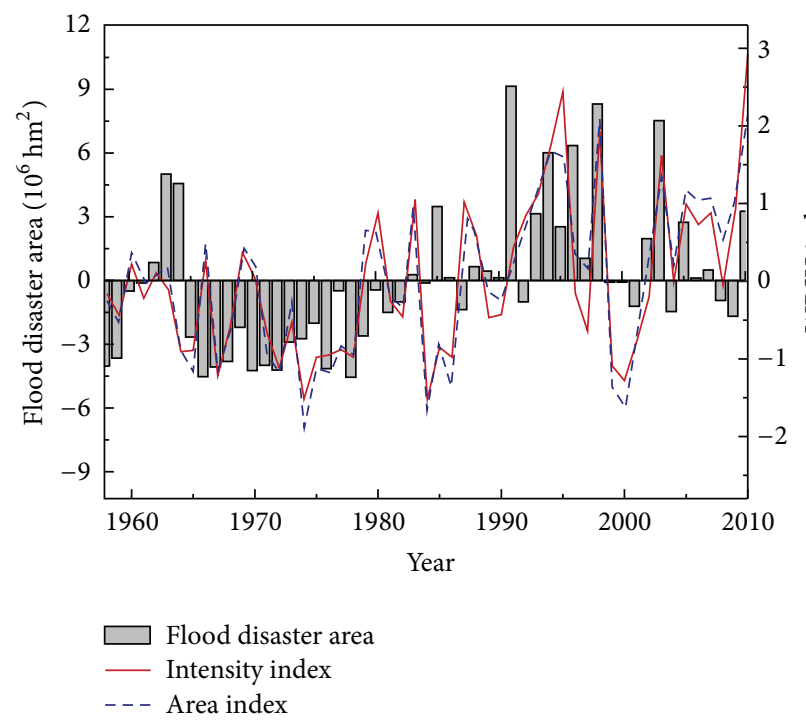

(c)

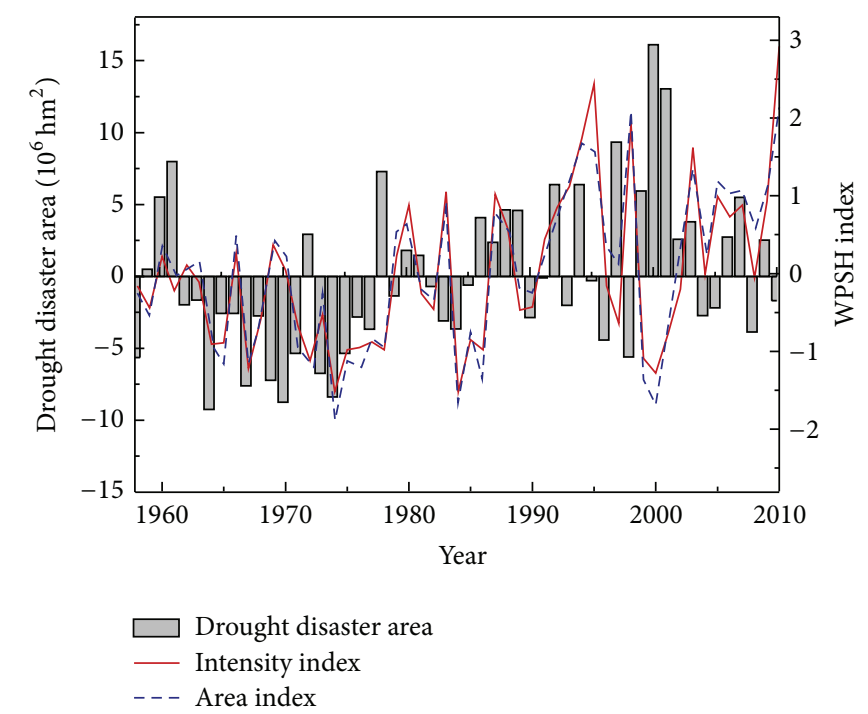

(b)

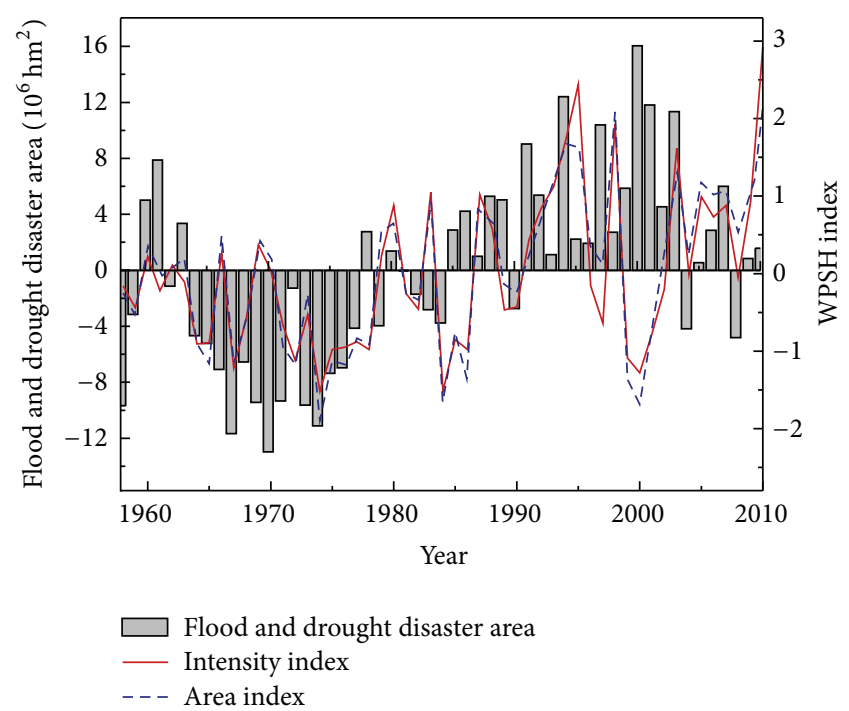

(d)

FIGURE 6: The variation of the SPI value, drought, and flood disaster area in China and the intensity and area index of WPSH.

is the mean circulation of the extreme drought and pluvial years, and the lower panel is the difference between the extreme drought (pluvial) years and the average annual circulation cell.

The longitude band of $105-120^{\circ} \mathrm{E}$ comprises the South China Sea, East China, Korea, and Japan and is representative of East Asia and the Western North Pacific (EA-WNP) summer monsoon. The EA-WNP monsoon circulations feature ascending motion with southerly flow at low levels [27]. During the period of 1959-1966 (DSC-PNC pattern), massive ascending airflow from South China extends to North China at $\sim 50^{\circ} \mathrm{N}$ (Figure $8(\mathrm{a})$ ), while, for the period of 1997-2003 (PSC-DNC pattern), the southerly airflow weakens and massive ascending airflow shrinks to South China at $\sim 30^{\circ} \mathrm{N}$ (Figure $8(\mathrm{~b})$ ). From the wind anomalies of the two periods, the upward wind anomalies can be found in North China and downward wind anomalies occur in South China for the DSC-PNC pattern (Figure 8(c)). On the contrary, the upward wind anomalies appear in South China while downward wind anomalies occur in North China for the PSC-DNC pattern (Figure $8(\mathrm{~d})$ ). These results agree well with the pattern of drought and pluvial events in China.

Figure 9 shows the spatial distribution of the mean and difference for the geopotential height and wind fields at $850 \mathrm{hPa}$ and $500 \mathrm{hPa}$. From this figure, East China is controlled by the southern summer monsoon and the wind speed grows gradually from South China to North China (Figures 9(a) and 9(b)). Obvious negative geopotential height anomalies and a cyclone atmospheric circulation can be found in North China for the DSC-PNC pattern at $850 \mathrm{hPa}$ and $500 \mathrm{hPa}$. In this pattern, southern wind anomalies occur in East China at $850 \mathrm{hPa}$ and $500 \mathrm{hPa}$, which indicates a 


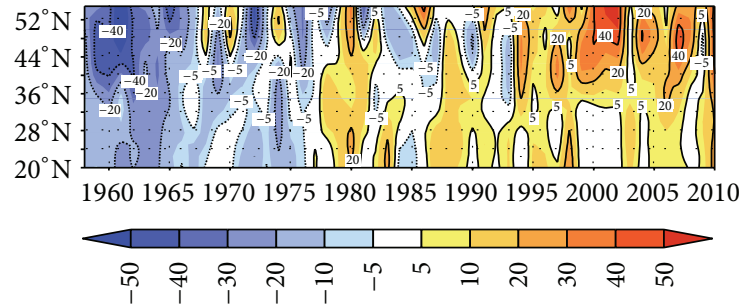

(a) Summer geopotential height anomalies at $500 \mathrm{hPa}$

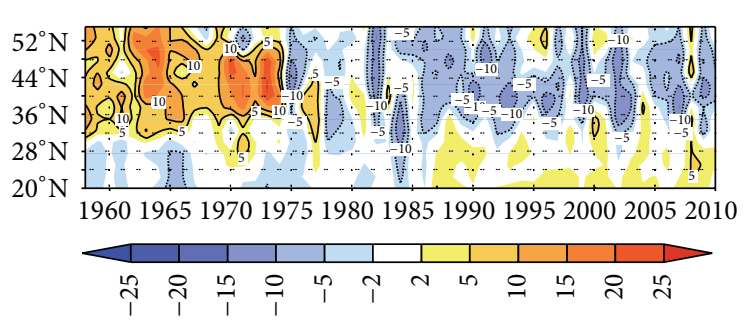

(c) Summer moisture content anomalies

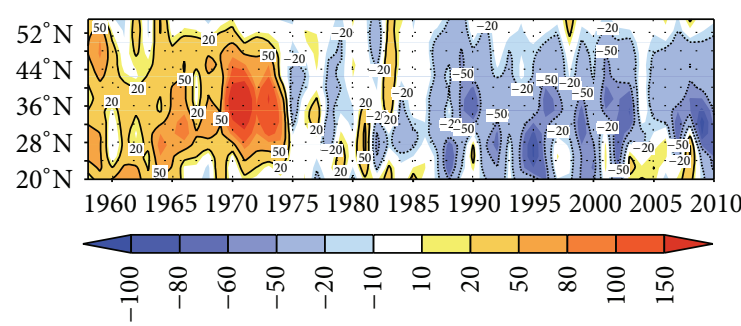

(b) Summer meridional moisture flux anomalies

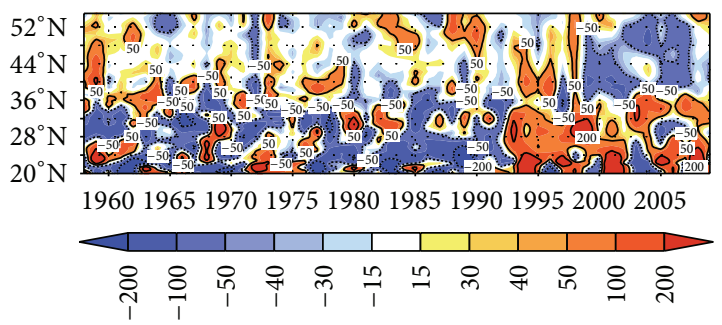

(d) Summer precipitation anomalies

Figure 7: Time-latitude anomalies cross section (averaged over $105-120^{\circ} \mathrm{E}$ ) of (a) geopotential height at $500 \mathrm{hPa}$, (b) meridional moisture flux, (c) moisture content, and (d) precipitation in summer.

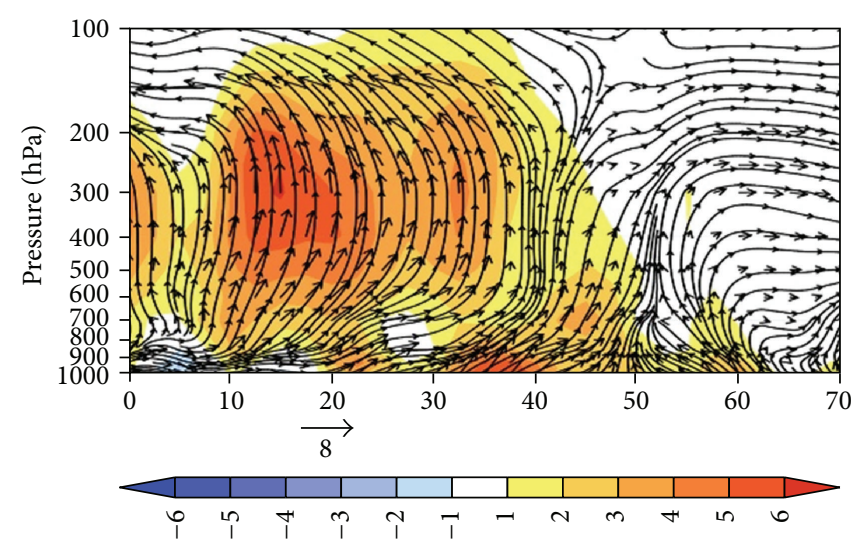

(a) 1959-1966 mean

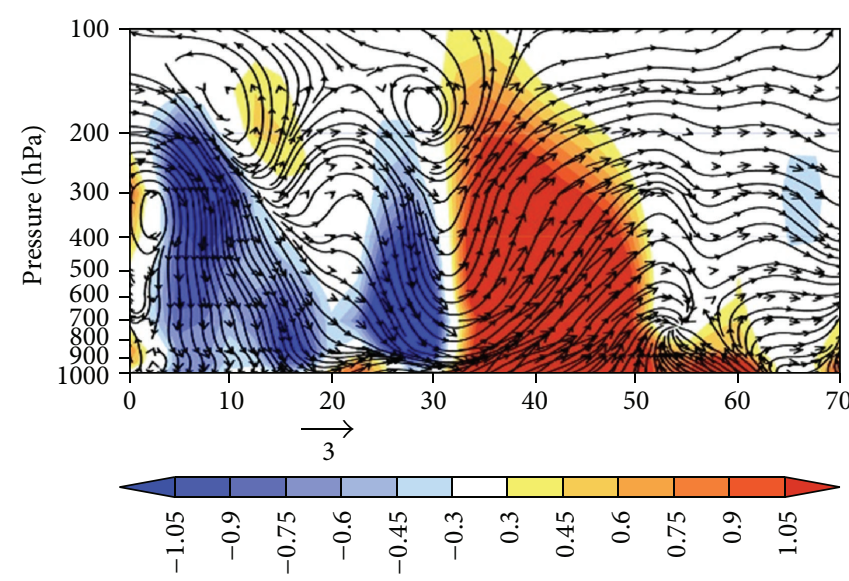

(c) 1959-1966 difference

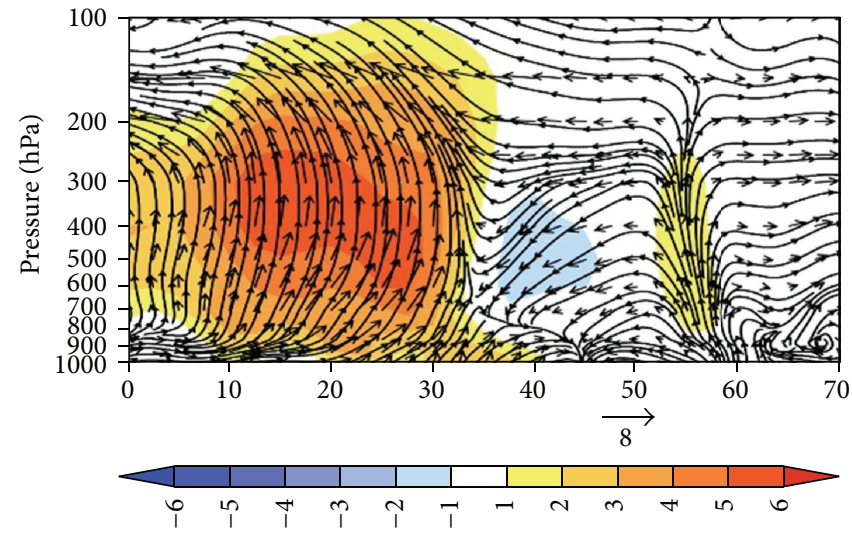

(b) 1997-2003 mean

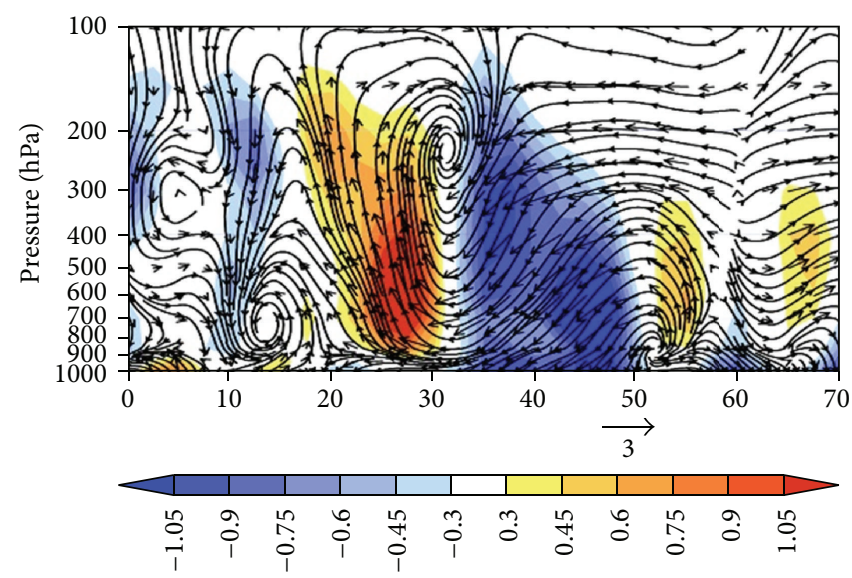

(d) 1997-2003 difference

FIGURE 8: The mean and difference of meridional circulation cells averaged over 105-120 E. The mean for the periods of (a) 1959-1966 and (b) 1997-2003, (c) the difference between 1959-1966 and 1958-2010, and (d) the difference between 1997-2003 and $1958-2010$ (unit: 0.1 m/s). 


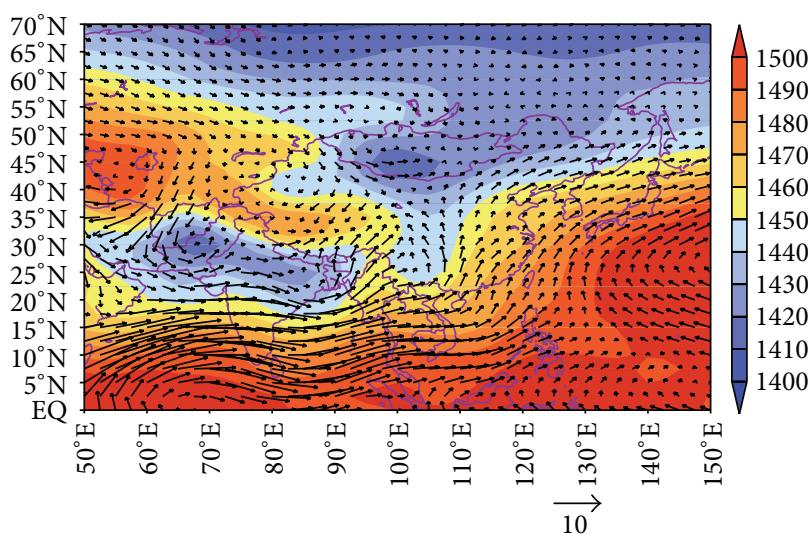

(a) 1958-2010 mean at $850 \mathrm{hPa}$

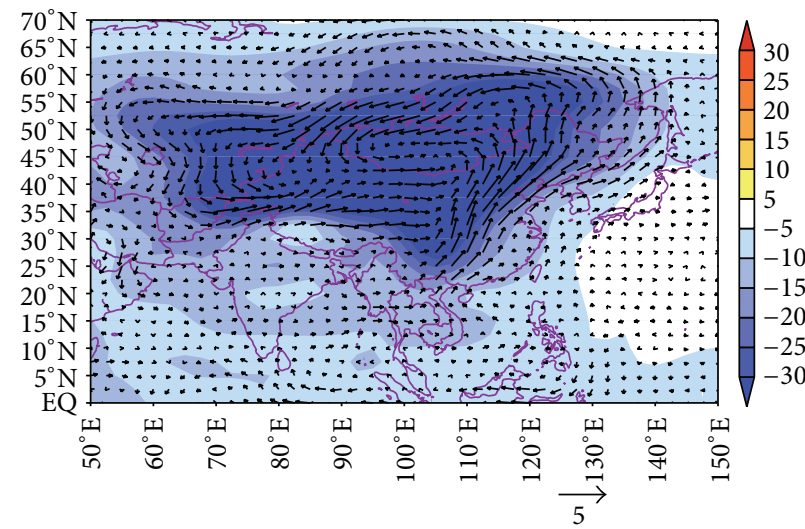

(c) 1959-1966 difference at $850 \mathrm{hPa}$

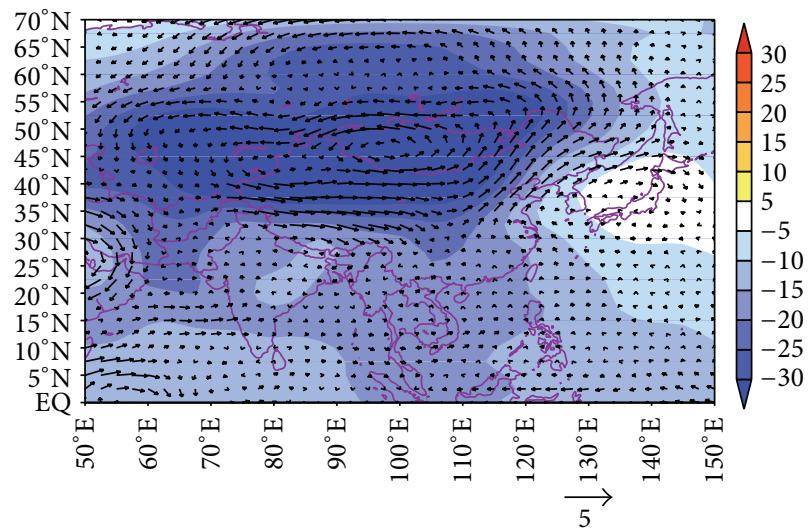

(e) 1959-1966 difference at $500 \mathrm{hPa}$

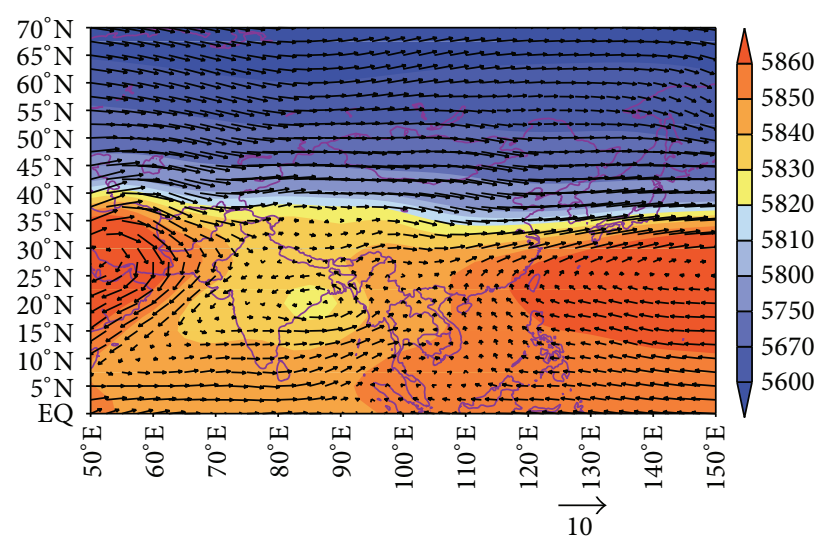

(b) 1958-2010 mean at $500 \mathrm{hPa}$

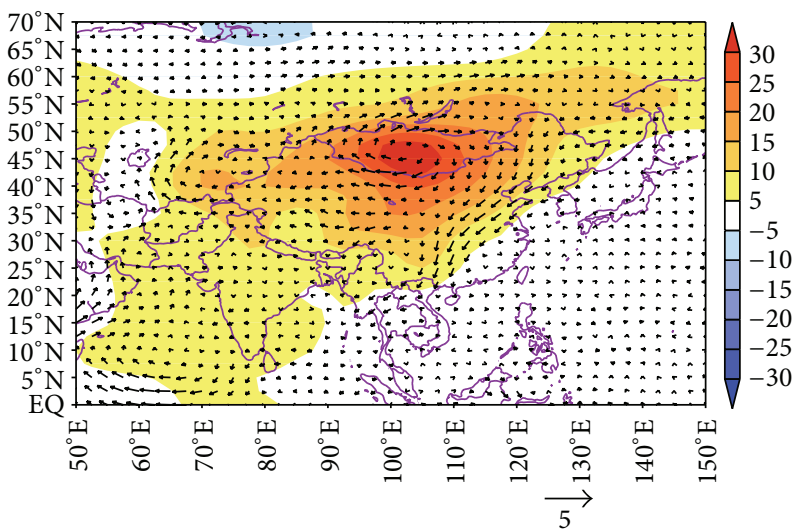

(d) 1997-2003 difference at $850 \mathrm{hPa}$

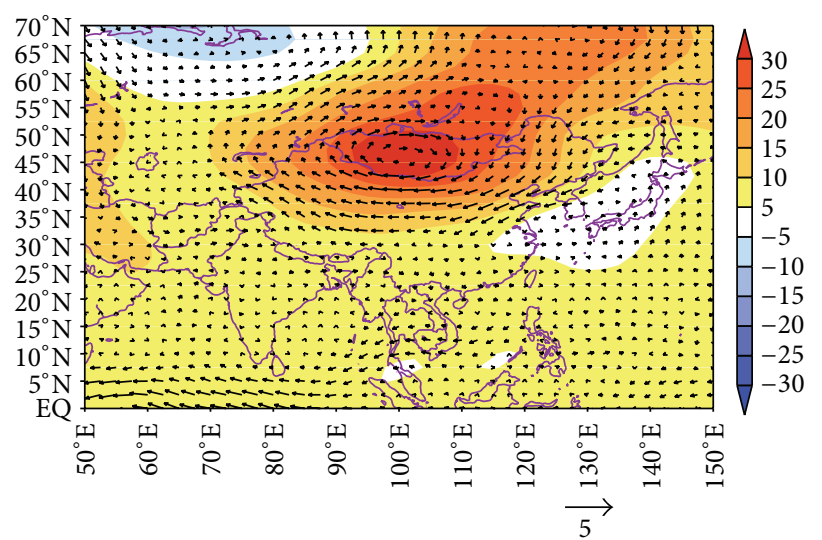

(f) 1997-2003 difference at $500 \mathrm{hPa}$

FIGURE 9: The mean and difference of the geopotential height and wind field at $850 \mathrm{hPa}$ and $500 \mathrm{hPa}$ in East Asia during the summer. The shading indicates the geopotential height.

strong East Asian summer monsoon. For the PSC-DNC pattern, the geopotential height anomalies and the atmospheric circulation are quite opposite to the DSC-PNC pattern. Northern wind anomalies follow along with positive geopotential height anomalies and the anticyclone in North China at $850 \mathrm{hPa}$ and $500 \mathrm{hPa}$ which indicates a weak East Asian summer monsoon. Huang et al. [3] also stated that the occurrence of severe floods in the Yangtze and Huaihe River valleys and prolonged droughts in North China are linked, respectively, to the background interannual and interdecadal variability of the East Asian monsoon (EAM) system.

\section{Conclusions}

The variabilities of the extreme drought and pluvial events in China and the associated large-scale atmospheric circulation 
from 1958 to 2010 have been analyzed to explore the changing features of the extreme drought and pluvial events in China and possible causes. Some interesting conclusions can be obtained as follows:

(1) The extreme drought and pluvial events in China increase significantly during the period $1958-2010$ as a whole. During the past 50 years, the pluvial events increased significantly in South China and Northwest China while the extreme drought events increased significantly in North China.

(2) The WPSH might play an important role in the drought and pluvial pattern of China. The strength of the WPSH is very weak during the DSC-PNC pattern period while it turns out to be very strong for the PSC-DNC pattern period, and negative (positive) geopotential high anomalies can be found in China during the DSC-PNC (PSC-DNC) pattern period.

(3) Negative WPSH anomalies can be found before the mid-1970s, while positive anomalies occur since the mid-1970s. The anomalies distribution of $Q_{v}, Q$, and $P$ is quite opposite to that of WPSH. The moisture content anomalies agree well with the meridional moisture flux distribution. During the period 19581975, more moisture content could be found in North China with more precipitation in North China.

(4) During the DSC-PNC pattern, massive ascending airflow from South China extends to North China at $\sim 50^{\circ} \mathrm{N}$ and obvious upward wind anomalies could be found in North China. And a cyclonic atmospheric circulation occurs in North China followed by negative geopotential height and southern wind anomalies at $850 \mathrm{hPa}$ and $500 \mathrm{hPa}$, which indicates a strong East Asian summer monsoon. As for the PSC-DNC pattern, the situation contrasts sharply with the DSCPNC pattern.

\section{Competing Interests}

The authors declare that they have no competing interests.

\section{Acknowledgments}

This paper is financially supported by the Major Program of the National Natural Science of China (Grant no. 51190091), project supported by Distinguished Young Scholars Fund of Nanjing Forestry University, National Natural Science Foundation of China (Grant no. 41171020), the State Key Laboratory of Satellite Ocean Environment Dynamics, Second Institute of State Oceanic Administration, Six Talent Peaks project in Jiangsu Province (Grant no. 2015-JY-017), and the Priority Academic Program Development of Jiangsu Higher Education Institutions (PAPD). The authors would like to thank the National Climate Centre in Beijing for providing valuable climate datasets.

\section{References}

[1] K. M. Andreadis and D. P. Lettenmaier, "Trends in 20th century drought over the continental United States," Geophysical Research Letters, vol. 33, no. 10, Article ID L10403, 2006.
[2] E. R. Garnett and M. L. Khandekar, "The impact of large-scale atmospheric circulations and anomalies on Indian monsoon droughts and floods and on world grain yields-a statistical analysis," Agricultural and Forest Meteorology, vol. 61, no. 1-2, pp. 113-128, 1992.

[3] R. Huang, J. Chen, and G. Huang, "Characteristics and variations of the East Asian monsoon system and its impacts on climate disasters in China," Advances in Atmospheric Sciences, vol. 24, no. 6, pp. 993-1023, 2007.

[4] B. G. Hunt, "Global characteristics of pluvial and dry multiyear episodes, with emphasis on megadroughts," International Journal of Climatology, vol. 31, no. 10, pp. 1425-1439, 2011.

[5] A. K. Mishra and V. P. Singh, "A review of drought concepts," Journal of Hydrology, vol. 391, no. 1-2, pp. 202-216, 2010.

[6] A. Dai, K. E. Trenberth, and T. Qian, "A global dataset of Palmer Drought Severity Index for 1870-2002: relationship with soil moisture and effects of surface warming," Journal of Hydrometeorology, vol. 5, no. 6, pp. 1117-1130, 2004.

[7] J. Qiu, "China drought highlights future climate threats," Nature, vol. 465, no. 7295, pp. 142-143, 2010.

[8] D. Shankman, B. D. Keim, and J. Song, "Flood frequency in China's Poyang lake region: trends and teleconnections," International Journal of Climatology, vol. 26, no. 9, pp. 12551266, 2006.

[9] P. J. Ward, B. Jongman, M. Kummu, M. D. Dettinger, F. C. Sperna Weiland, and H. C. Winsemius, "Strong influence of El Niño Southern Oscillation on flood risk around the world," Proceedings of the National Academy of Sciences of the United States of America, vol. 111, no. 44, pp. 15659-15664, 2014.

[10] Z. W. Wu, J. P. Li, J. H. He, and Z. H. Jiang, "Occurrence of droughts and floods during the normal summer monsoons in the mid- and lower reaches of the Yangtze River," Geophysical Research Letters, vol. 33, no. 5, article L05813, 2006.

[11] R. R. Heim Jr., "A review of twentieth-century drought indices used in the United States," Bulletin of the American Meteorological Society, vol. 83, no. 8, pp. 1149-1165, 2002.

[12] T. McKee, N. Doesken, and J. Kleist, "The relationship of drought frequency and duration to time steps," in Proceedings of the 8th Conference on Applied Climatology, pp. 179-184, Anaheim, Calif, USA, 1993.

[13] J. Li, S. Zhou, and R. Hu, "Hydrological drought class transition using spi and sri time series by loglinear regression," Water Resources Management, vol. 30, no. 2, pp. 669-684, 2016.

[14] X. Lana and A. Burgueño, "Spatial and temporal characterization of annual extreme droughts in Catalonia (Northeast Spain)," International Journal of Climatology, vol. 18, no. 1, pp. 93-110, 1998.

[15] X. Lana, C. Serra, and A. Burgueño, "Patterns of monthly rainfall shortage and excess in terms of the standardized precipitation index for Catalonia (NE Spain)," International Journal of Climatology, vol. 21, no. 13, pp. 1669-1691, 2001.

[16] Z. Zhang, Q. Zhang, X. Chen, J. Zhang, and J. Zhou, "Statistical properties of moisture transport in East Asia and their impacts on wetness/dryness variations in North China," Theoretical and Applied Climatology, vol. 104, no. 3-4, pp. 337-347, 2011.

[17] H. Tao, H. Borth, K. Fraedrich, A. Schneidereit, and X. Zhu, "Hydrological extremes in the Aksu-Tarim River Basin: climatology and regime shift," Climate Dynamics, vol. 46, no. 7-8, pp. 2029-2037, 2016. 
[18] M. J. Hayes, M. D. Svoboda, D. A. Wilhite, and O. V. Vanyarkho, "Monitoring the 1996 drought using the standardized precipitation index," Bulletin of the American Meteorological Society, vol. 80, no. 3, pp. 429-438, 1999.

[19] Y. Ding, Z. Wang, and Y. Sun, "Inter-decadal variation of the summer precipitation in East China and its association with decreasing Asian summer monsoon. Part I: observed evidences," International Journal of Climatology, vol. 28, no. 9, pp. 1139-1161, 2008.

[20] J. He, J. Ju, Z. Wen, J. Lü, and Q. Jin, "A review of recent advances in research on Asian monsoon in China," Advances in Atmospheric Sciences, vol. 24, no. 6, pp. 972-992, 2007.

[21] C. Zhu, X. Zhou, P. Zhao, L. Chen, and J. He, "Onset of East Asian subtropical summer monsoon and rainy season in China," Science China Earth Sciences, vol. 54, no. 12, pp. 18451853, 2011.

[22] M. Barlow, H. Cullen, and B. Lyon, "Drought in Central and Southwest Asia: La Niña, the warm pool, and Indian Ocean precipitation," Journal of Climate, vol. 15, no. 7, pp. 697-700, 2002.

[23] Y. Ding, Y. Sun, Z. Wang, Y. Zhu, and Y. Song, "Interdecadal variation of the summer precipitation in China and its association with decreasing Asian summer monsoon part II: possible causes," International Journal of Climatology, vol. 29, no. 13, pp. 1926-1944, 2009.

[24] Z. Ma and C. Fu, "Interannual characteristics of the surface hydrological variables over the arid and semi-arid areas of northern China," Global and Planetary Change, vol. 37, no. 3-4, pp. 189-200, 2003.

[25] B. Wu, "Weakening of Indian summer monsoon in recent decades," Advances in Atmospheric Sciences, vol. 22, no. 1, pp. 21-29, 2005.

[26] X. Jiang, Y. Li, S. Yang, and R. Wu, "Interannual and interdecadal variations of the South Asian and western Pacific subtropical highs and their relationships with Asian-Pacific summer climate," Meteorology and Atmospheric Physics, vol. 113, no. 3, pp. 171-180, 2011.

[27] M. D. Chou, C. H. Wu, and W. S. Kau, "Large-scale control of summer precipitation in Taiwan," Journal of Climate, vol. 24, no. 19, pp. 5081-5093, 2011.

[28] S. Piao, P. Ciais, Y. Huang et al., "The impacts of climate change on water resources and agriculture in China," Nature, vol. 467, no. 7311, pp. 43-51, 2010.

[29] Z. Zhang, H. Tao, Q. Zhang, J. Zhang, N. Forher, and G. Hörmann, "Moisture budget variations in the Yangtze River Basin, China, and possible associations with large-scale circulation," Stochastic Environmental Research and Risk Assessment, vol. 24, no. 5, pp. 579-589, 2010.

[30] Z. Zhang, Q. Zhang, C. Xu, C. Liu, and T. Jiang, "Atmospheric moisture budget and floods in the Yangtze River basin, China," Theoretical and Applied Climatology, vol. 95, no. 3, pp. 331-340, 2009.

[31] S. Sun and M. Ying, "Subtropical high anomalies over the Western Pacific and its relations to the Asian monsoon and SST anomaly," Advances in Atmospheric Sciences, vol. 16, no. 4, pp. 559-568, 1999.

[32] B. Lloyd-Hughes and M. A. Saunders, "A drought climatology for Europe," International Journal of Climatology, vol. 22, no. 13, pp. 1571-1592, 2002.

[33] A. Hannachi, I. T. Jolliffe, and D. B. Stephenson, "Empirical orthogonal functions and related techniques in atmospheric science: a review," International Journal of Climatology, vol. 27, no. 9, pp. 1119-1152, 2007.

[34] H. F. Kaiser, "The varimax criterion for analytic rotation in factor analysis," Psychometrika, vol. 23, no. 3, pp. 187-200, 1958.

[35] G. R. North, "Empirical orthogonal functions and normal modes," Journal of the Atmospheric Sciences, vol. 41, no. 5, pp. 879-887, 1984.

[36] W. Zhou, J. Chan, and C. Li, "South China Sea summer monsoon onset in relation to the off-equatorial ITCZ," Advances in Atmospheric Sciences, vol. 22, no. 5, pp. 665-676, 2005.

[37] T. Yasunari, "Impact of Indian monsoon on the coupled atmosphere/ocean system in the tropical pacific," Meteorology and Atmospheric Physics, vol. 44, no. 1, pp. 29-41, 1990.

[38] G. Zeng, W. C. Wang, Z. Sun, and Z. Li, "Atmospheric circulation cells associated with anomalous East Asian winter monsoon," Advances in Atmospheric Sciences, vol. 28, no. 4, pp. 913-926, 2011.

[39] D. Qian, Z. Guan, and L. Wang, "Inter decadal variations of west pacific subtropical high area and changes in summer precipitation over China in boreal summer during the last 57 years," Transactions of Atmospheric Sciences, vol. 32, no. 5, pp. 677-685, 2009 (Chinese). 

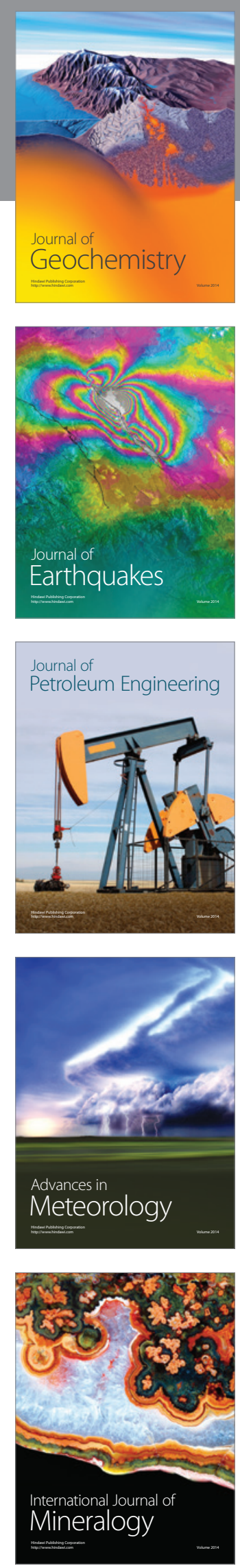
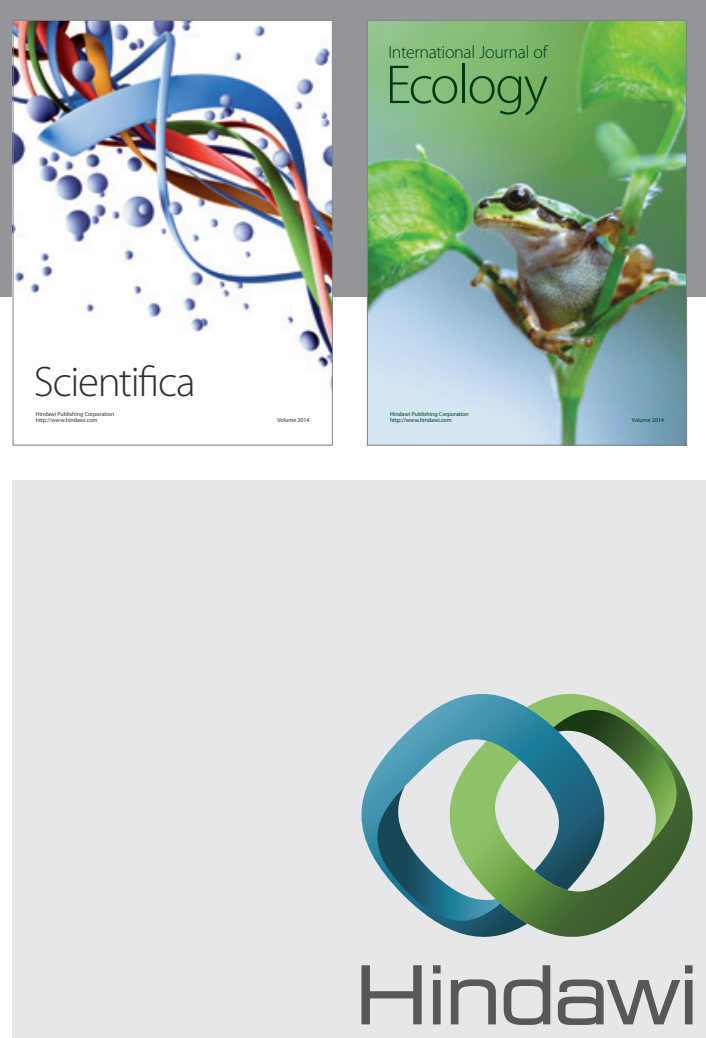

Submit your manuscripts at

http://www.hindawi.com
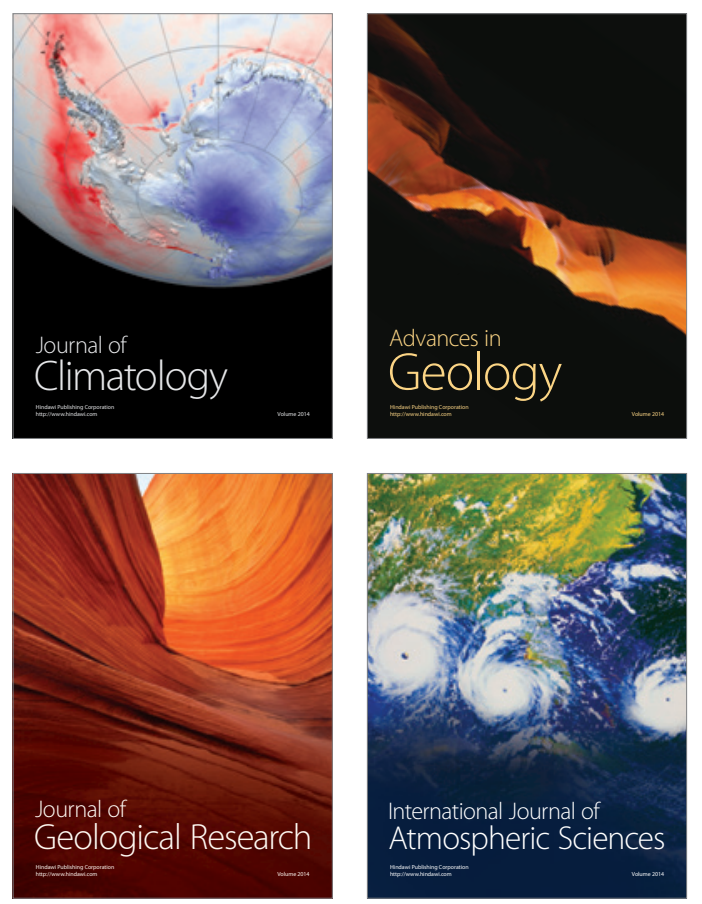

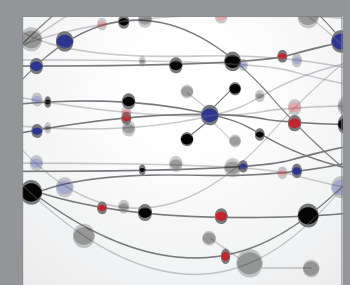

The Scientific

\section{World Journal}
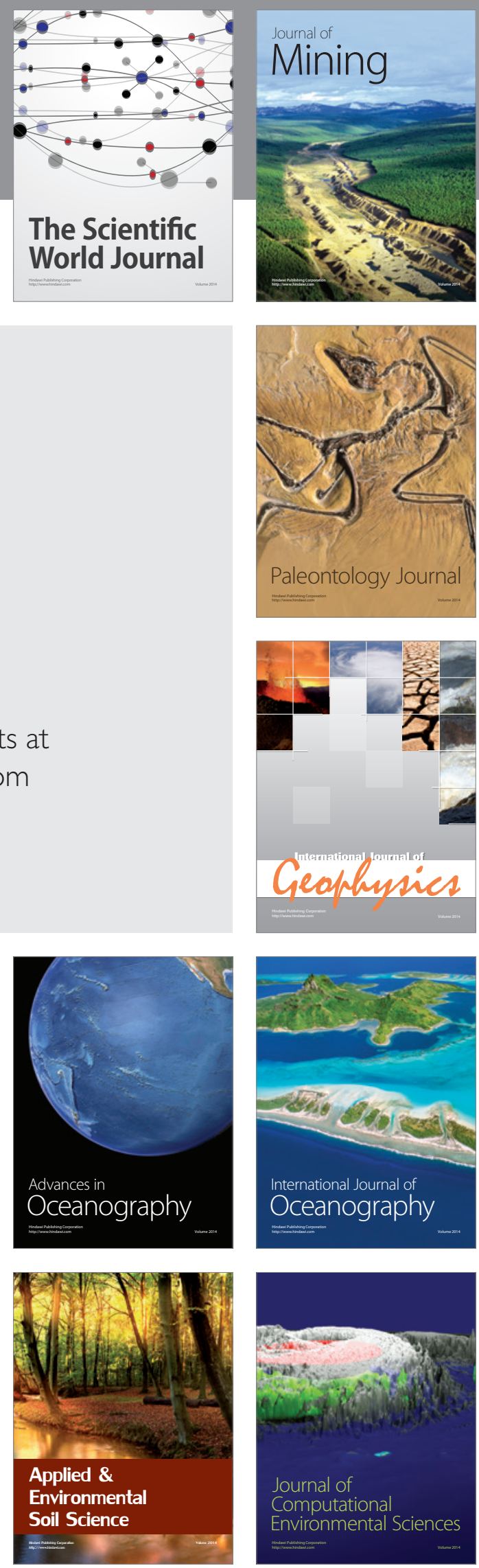